\title{
Expression of cytochrome P450 aromatase isoforms in female Alburnus tarichi (Guldenstaedtii, 1814)
}

\section{Dişi Van balığı (Alburnus tarichi, Guldenstaedtii, 1814)’nda sitokrom P450 aromataz izoformlarının ekspresyonu}

\author{
Guler Unal $^{1^{*}}$ - Emily Marquez ${ }^{2}$ - Mara H. O'brien ${ }^{3}$ • Pericles Stavropoulos ${ }^{4}$ • lan P. Callard ${ }^{5}$ \\ ${ }^{1}$ Adnan Menderes University, Faculty of Health Sciences, Aydın, Turkey \\ ${ }^{2}$ Boston University, Faculty of Science, Department of Biology, Boston, USA \\ ${ }^{3}$ Boston University, Faculty of Science, Department of Biology, Boston, USA \\ ${ }^{4}$ Missouri University, Department of Science and Technology, Missouri, USA.
}

${ }^{5}$ Boston University, Faculty of Science, Department of Biology, Boston, USA

*Corresponding author: histoloji35@gmail.com

Received date: 21.01 .2021

Accepted date: 22.03 .2021

How to cite this paper:

Unal, G., Marquez, E., O'brien, M.H., Stavropoulos, P. \& Callard, I.P. (2021). Expression of cytochrome P450 aromatase isoforms in female Alburnus tarichi (Guldenstaedtii, 1814) Ege Journal of Fisheries and Aquatic Sciences, 38(2), 247-252. DOI: 10.12714/egejfas.38.2.15

Abstract: In this study, we aimed to clone brain-derived Cyp19b and ovary-derived Cyp19a the P450 aromatase gene isoforms and to indicate the expression levels of these genes in the hypothalamus and ovary tissues from reproductively arrested ovarian development (RA) and non-arrested ovarian development (RN) Alburnus tarichi from Lake Van, Turkey. The expression levels of Cyp19b and Cyp19a genes were predominant in the hypothalamus and ovary, respectively. The level of Cyp19b mRNA was significantly lower in the hypothalamus and ovary from RA fish than in the hypothalamus and ovary from RN fish $(P<0.05)$. The expression level of Cyp19a was significantly lower in the ovary of RA fish $(P<0.05)$ than RN fish while no difference was found in the hypothalamus of both RA and RN fish $(P<0.05)$. According to these findings, we suggest that the RA fish represent a segment of the population and these fish may be more sensitive to endocrine disruption compound/s than others.

Keywords: P450 aromatase, gene expression, Alburnus tarichi, Lake Van

Öz: Bu çalışmanın amacı, Van Gölü'nden yakalanan dişi Alburnus tarichi'de P450 aromataz izoformları olan beyin kaynaklı Cyp19b ve ovaryum kaynaklı Cyp19a genlerini klonlanmak ve üreme bakımından ovaryum gelişimi engellenmiş (RA) ve ovaryum gelişimi normal olan (RN) balıklardan alınan hypothalamus ve ovaryum örneklerinde bu genlerin ekspresyon seviyelerini belirlemektir. Cyp19b gen ekspersyonu beyinde, Cyp19a gen ekspresyonu ise ovaryumda daha fazlaydı. Cyp19b mRNA seviyesi, RA balıkların ovaryum ve hipotalamusunda, RN balıkların ovaryum ve hipotalamusundan belirgin olarak düşüktü ( $P<0,05)$. CYP19a ekspresyon seviyesi, hem RN ve hem de RA balıkların hipotalamusunda fark bulunmazken RA balıkların ovaryumunda, RN balıkların ovaryumundan belirgin olarak düşüktü $(P<0,05)$. Bu sonuçlara bize, RA balıkların populasyonun bir parçası olduğunu ve bu balıkların endokrin bozucu bileşik veya bileşiklere diğer balıklardan daha çok duyarlı olabileceğini düşündürmektedir.

Anahtar kelimeler: P450 aromatase, gen ekspresyonu, Alburnus tarichi, Van Gölü

\section{INTRODUCTION}

Increasing P450 aromatase is a catalyze enzyme which converts testosterone to estrogens. In most vertebrates, it is encoded on a single Cyp19 gene, two structurally and functionally different Cyp19 genes are found in many teleost, (Kishida and Callard, 2001; Chang et al., (2005); Greytak et al., 2005; Barney et al., 2008; Lange et al., 2008). These genes are expressed mainly in the ovary and brain and they encode Cyp19a/Cyp191a and Cyp19b/Cyp191a2, respectively. The Cyp19b gene is expressed earlier than Cyp19a during early embryonic development and has an important role in gonadal sex differentiation (Callard et al., 2001; Chiang et al., 2001; Barney et al., 2001). However, in adult fish, brain aromatase activity is high, approximately 100 - to 1000 -fold greater than that detected in the similar brain regions of mammals (Pasmanik and Callard, 1985).

The roles of Cyp19a and Cyp19b genes in developmental programming and estrogen regulation are different (Kishida and Callard, 2001; Tchoudakova et al., 2001). In unfertilized zebrafish eggs, aromatase isoforms are derived maternally but Cyp19b expression starts 5hpf much earlier than Cyp19a (48 hpf) post-fertilization. In addition, the expression of Cyp19b but not Cyp19a mRNA is up-regulated by $17 \beta$-estradiol $\left(E_{2}\right)$ (Sawyer et al., 2006). Cyp1919b is a potential target of endocrine disrupting chemicals EDCs). In some studies, Cyp 19b mRNA is strongly up-regulated by $E_{2}$ and $E_{2}$ mimics EDCs such as nonylphenol(NP) and 17alpha-ethinyl estradiol $\left(E_{2}\right)$ whereas Cyp19a was largely unaffected (Kazeto et al., 2003; Fenske and Segner, 2004; Cheshenko et al., 2006). Similarly, the levels Cyp19a mRNA in ovary, testis and brain did not change after in vitro treatment with $\mathrm{E}_{2}$, testosterone and 17,20ß,21-trihydroxy-4-pregnen-3-one for six hours (Nunez and Applebaum, 2006). The $A$. tarichi, the vitellogenesis starts about in October and continues to March (Unal et al., 1999). The sampling fish from Van Edremit Region (VER) of Lake Van 
(Figure 1) have been previously described as reproductively non-arrested (RN) and reproductively arrested (RA) fish (Ünal et al., 2007). In that study, RA fish have the following characteristics assessed at collection and sacrifice: lower gonadosomatic index, lower plasma $\mathrm{E}_{2}$ levels, and reduced ovaries with oocytes that are developmentally blocked before the vitellogenic stage. We previously indicated di-(2-ethlhexyl) phthalate (DEHP) in the sediment from VER of Lake Van (Unal et al., 2014). At the same study, low estrogen receptor alfa (ERa) and vitellogenin mRNA levels were measured in the liver of RA fish. DEHP is widely used as a plasticizer in flexible vinyl products. Plastics may contain from 1 to $40 \%$ DEHP by weight and are used in many consumer products. DEHP is the most comment pollutant chemical of our general environment, and it have a potential to accumulate in soil, sediment, underground water and also air because of its low soluble and vaporization abilities (EPA, 2001). Domestic and industrial wastewater treatment plants (Marttinen et al., 2003) are the major source of DEHP contaminant to fresh water such as river and lake. There is also a small factory between university campus and waste treatment plant, in Van (Figure.1).

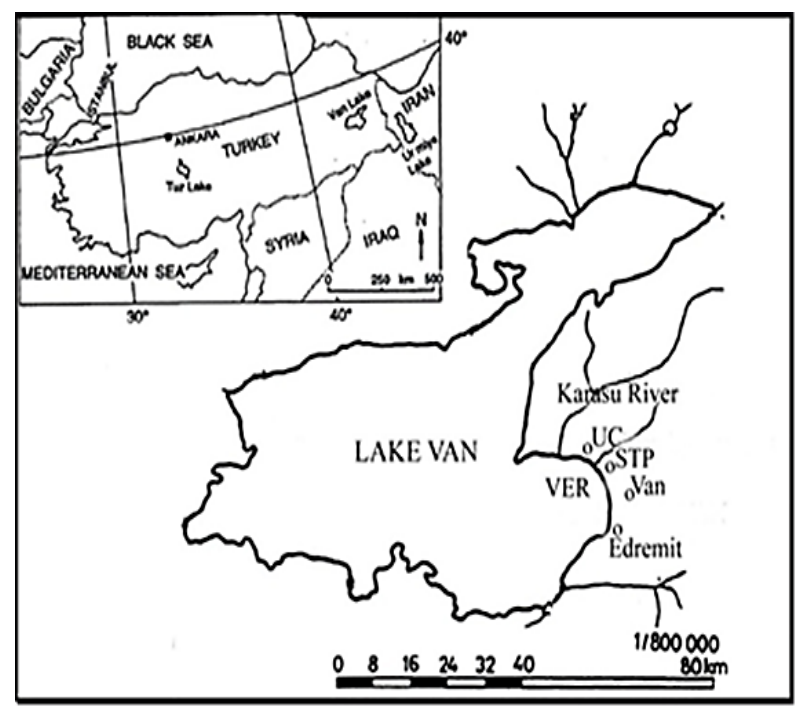

Figure 1. Fish sampling sites at lake Van. Ver, Van Edremit region; stp, sewage treatment plant; uc, university campus

The purpose of this study was to determine the cDNA sequences of P450 aromatese subtypes (Cyp19b and Cyp19a), and to measure the mRNA expressions in the hypothalamus and ovary of RN (vitellogenic) and RA female $A$. tarichi from VER in Lake Van, a site with known contamination by household waste and potentially contaminated by other sources of pollution. A. tarichi is a cyprinid fish endemic to Lake Van basin, in Turkey, and it has been an economical important for this region.

\section{MATERIALS AND METHODS}

\section{Fish collection and tissue sampling}

RN female $A$. tarichi were caught by netting from VER of Lake Van, Turkey (Figure 1) in April 2010 and 2013. They were transferred to the laboratory in aired water tank and they killed by decapitation. After opened the abdomen of fish, RA and RN fish were separated according to ovaries and testis structure (Ünal et al., 2007). The ovaries, liver and brain were removed after dissection of 4-5 years old fish (about 20-21 cm fork length). For this $10 \mathrm{RN}$ and $10 \mathrm{RA}$ female fish were used. Tissues were treated with RNA-later (Sigma), frozen at $-80^{\circ} \mathrm{C}$ and shipped to Prof.Dr. lan P. Callard's laboratory on dry ice. They were stored at $-80^{\circ} \mathrm{C}$ until RNA extraction.

\section{RNA extraction, cloning and gene expression analysis}

Total RNA was extracted from frozen ovary and hypothalamic tissues using Trizol (Sigma Aldrich St. Lous, MO) following the manufacturer's instructions. The hypothalamus was removed with the brain and trimmed from the sides and the area containing the hypothalamus was used for RNA extraction. RNAs were run on a $1 \%$ agarose gel to assess quality, and total RNA quantified using a Nanodrop (Thermo Fisher Scientific). $5 \mu \mathrm{g}$ of total RNA from each tissue was reverse transcribed using SuperScript II transcriptase and oligo (dT) 20 primer according to the manufacturer's instructions (Invitrogen). PCR was performed in a $50 \mu$ final volume using Sigma Readymix (Sigma). PCR conditions and primers used to clone partial CDNAs of CYP19B and CYP19A were taken from Tchoudakova and Callard (1998) and Lange et al. (2008), respectively (Table 1). The amplification products were excised from the gel, and extracted using the MinElute gel extraction kit (Qiagen). The PCR fragment were ligated into pGEM T-easy plasmid (Promega) and transformed into competent E. coli cells (Bioline). After amplification, the DNA fragments were extracted using the Wizard Miniprep kit (Invitrogen) and sequenced (MWG/Eurofins Operon, Huntsville, AL, USA).

The real-time quantitative PCR (qPCR) primers were designed using PrimerExpress 2.0 (Applied Biosystems, Foster City, CA, USA) from deduced cDNA sequences (Table 1). An amplification efficiency value was obtained for each primer by using serial dilutions of CDNA of each tissue. The reverse transcribed mRNA was measured by qPCR using targetspecific assays. qPCR was performed on an ABI Prism 7900HT sequence detection system (Applied Biosystems) with SYBR green fluorescent label. $\beta$-actin, the reference gene, also was cloned from hypothalamus, ovary and liver tissues of RN fish and measured the expression level of its. It was used as an internal control to normalize mRNA expression values. 
Table 1. Primers for CYP19B and CYP19B Cloning and Quantitative PCR in A. tarichi. Primer direction is noted. F, forward; R, reverse; $q \mathrm{PCR}$, quantitative PCR. $\beta$-actin was used to normalize the qPCR data from the $A$. tarichi

\begin{tabular}{lllll}
\hline $\begin{array}{l}\text { Primer } \\
\text { No }\end{array}$ & $\begin{array}{l}\text { Oligol } \\
\text { direction }\end{array}$ & Sequence $\left(\mathbf{5}^{\prime}\right.$ to $\mathbf{3}^{\prime}$ ) & Position & Reference \\
\hline CYP19B & & & & \\
1 & CYP19B-F & AGGTWCCAKCCNGTBGTSGACTTC & $1173-1197$ & Tchoudakova and Callard (1998) \\
2 & CYP19B-R & CACCATNGCDATRWRYTTNCC & $1395-1416$ & Tchoudakova and Callard (1998) \\
3 & CYP19B-F & RGTBTGGATCWVYGGAGARGA & $338-359$ & Tchoudakova and Callard (1998) \\
4 & CYP19B-R & GTAACGACTGGGACGCTGT & $167-186$ & From Alburnus tarichi \\
5 & qCYP19B-F & GCACAAGTCCGAGTTCTTCA & $943-962$ & \\
6 & qCYP19B-R & CCGAACGGCTGGAAGTAA & $1015-1032$ & \\
CYP19A & & & & \\
1 & CYP19A-F & GGNYTNCARTGYATHGGNATG & & Lange et al., (2008) \\
2 & CYP19A-R & GTRTCNGGNGCNGCDAT & & \\
3 & qCYP19A-F & CTGCACAAGAAGCACAAGAGAGA & $358-378$ & \\
4 & qCYP19A-R & TCGAGTTTTCTGCATGTGTCA & $458-479$ & \\
\hline
\end{tabular}

\section{Data analysis}

Data deduced by qPCR were first analyzed using the Applied Biosystems Sequence Detection System 2.2.1. Analyses were conducted with qGene to normalize the data obtained (Simon, 2003). Relative quantification was performed by a modified comparative critical threshold method that corrects for different PCR amplification efficiencies among primer pairs (Simon, 2003). Normalized gene expression is given as mean normalized expression $(\mathrm{MNE})=\left(\mathrm{E}_{\mathrm{PPI}}{ }^{\text {meanCTPP1}}\right) / \mathrm{E}$ $\left.\mathrm{ERa}^{\text {meanCTERa }}\right)$ where $\mathrm{E}=\mathrm{PCR}$ efficiency $\left(\mathrm{E}=10^{-(1 / \text { slope })}\right)$ and mean threshold cycle (CT) is the average CT from the three replicates (Pfaffl, 2001). Data were rejected if the \%SEM was greater than $20 \%$. The average MNE was determined for each set of replicates obtained from an individual animal, and standard deviation calculated for each SE of MNE. The MNEs were then averaged for each group analyzed. Statistical analyses were performed using the PROG GLM in the SAS 9.3 package. Student's t tests were used to compare expression of Cyp19b and Cyp19a genes. Significance was set at $P<0.05$.

\section{RESULTS}

We isolated a partial of Cyp19b and Cyp19a cDNA from vitellogenic $A$. tarichi hypothalamus and ovary, respectively. For the isolation of Cyp19b and Cyp19a genes, they were amplified by PCR using degenerate and designed primers (Table 1). Isolated sequences of Cyp19b (GenBank accession no. JF2975565.1) and Cyp19agenes (GenBank Accession no. JF297564.1) were deposited in GenBank. Expression of Cyp19b and Cyp19a genes was observed in the hypothalamus and ovary of fish (Figure 2). The expression of Cyp19b and Cyp19a was dominant in the hypothalamus and ovary, respectively. The level of Cyp $19 \mathrm{~b}$ mRNA in the hypothalamus was measured 992.3-fold higher than ovary while Cyp19a mRNA in the ovary was 14.3-fold higher than hypothalamus.

The Cyp19b and Cyp19a expression levels were measured in the hypothalamus and ovary of both RN and RA A. tarichi. The levels of Cyp19b mRNA were significantly lower in the hypothalamus (Figure $3 \mathrm{~A}$ ) and ovary (Figure $3 \mathrm{~B}$ ) of RA fish $(P<0.05)$. The expression of Cyp19a was significantly lower in the ovary of RA fish than RN fish $(P<0.05)$ while no significant difference was apparent in Cyp19a expression in the hypothalamus of RN and RA fish ( $P>0.05$; Figure 4$)$.

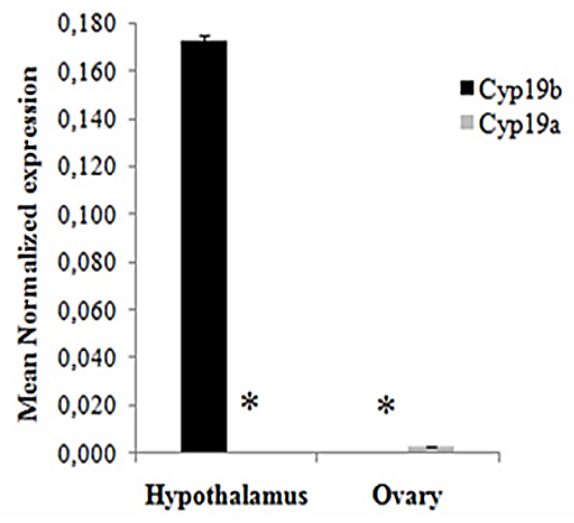

Figure 2. Tissue Distribution of $A$.tarichi Aromatase Isomers. mRNA levels of Cyp19b and Cyp19a in the hypothalamus and ovary from vitellogenic fish. Letters indicate significant differences 

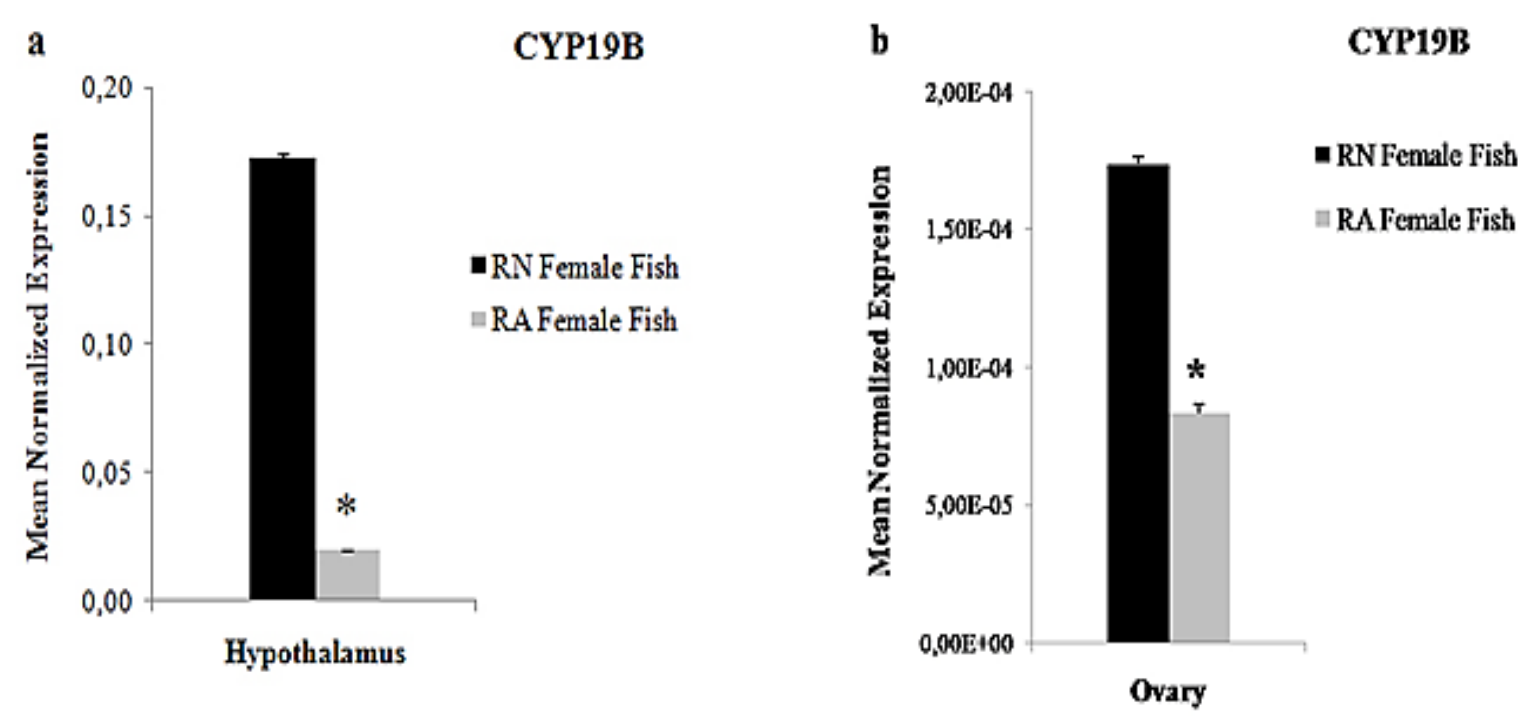

Figure 3. Cyp19b mRNA levels in the hypothalamus (a) and ovary (b) of reproductively non-arrested (RN) and reproductively arrested (RA) female $A$. tarichi sampled from Van Edremit Region, Lake Van. Eachbar shows mRNA levels normalized with $\beta$-actin. Asterisks indicate significant differences $(P<0.05)$

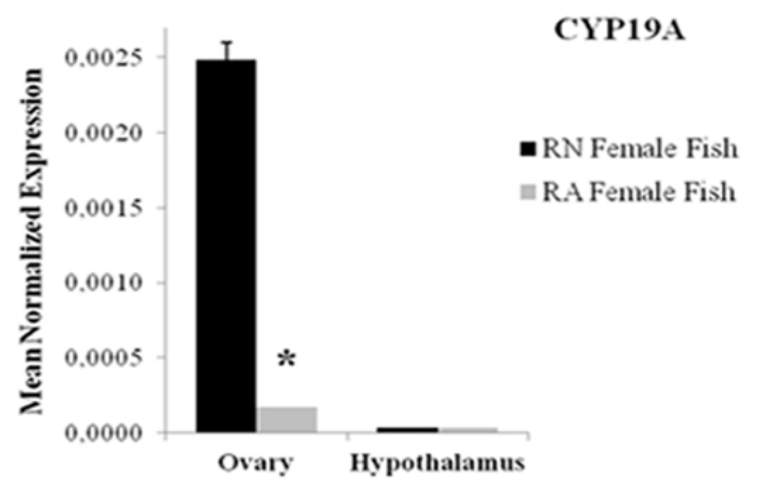

Figure 4. Cyp19a mRNA Levels in Ovary and Hypothalamus of Reproductively Non-arrested (RN) and Reproductively Arrested (RA) Female A. tarichi Sampled from Van Edremit Region, Lake Van. Each bar shows mRNA levels normalized with $\beta$-actin. Asterisks indicate significant differences $(P<0.05)$

\section{DISCUSSION}

In this study, we measured the expression levels of Cyp19b and Cyp19a genes in the hypothalamus and ovary of RN (vitellogenic stage) and RA A. tarichi from VER of Lake Van. Previous studies of fish determined that two Cyp19 loci have been isolated, brain-derived Cyp1919b and ovary-derived Cyp19a, and they have different functional programs (Callard et al., 2001; Cheshenko et al., 2008; Kishida and Callard, 2001; Tchoudakova and Callard, 1998; Tchoudakova et al., 2001). Cyp19b and Cyp19a mRNA were both detected in the hypothalamus and ovary of RN $A$. tarichi, andCyp $19 \mathrm{~b}$ mRNA abundance was $\sim 993$-fold higher in the hypothalamus than in ovary whereas Cyp19a mRNA was $\sim 71$-fold higher in the ovary than in the hypothalamus. In teleost fish, it is well known that the brain aromatase activity (10-100-fold) and expression are higher than ovary (Greytak et al., 2005; Pasmanik and Callard, 1985; Villeneuve, 2006).

The level of Cyp19b transcript was found to be significantly lower in RA fish tissues than in RN fish. Several studies indicate that $P 450$ aromatase $B$ (not the P450 aromataseA) transcripts are up-regulated by $E_{2}$ (Barney et al., 2008; Kishida and Callard, 2001; Kishida et al., 2001; Sawyer et al., 2006; Tchoudakova et al., 2001) due to the fact that the 5'-flanking region of the Cyp19b gene includes two estrogen response element (EREs), and an ERE half-site (ERE1/2) (Callard et al., 2001). In accordance with these results, the low Cyp19b expression in the hypothalamus and ovary of RA fish correlates with low plasma $\mathrm{E}_{2}$ level and GSI in RA fish (Ünal et al., 2007).

In fish, it is well known that the physiological functions of brain aromatase are implicated in development of central the nervous system, regeneration and sex differentiation (Forlano et al., 2001) while ovarian aromatase is involved in ovarian differentiation (Kwon et al., 2001; Matsuoka et al., 2006) and gametogenesis (Kazeto et al., 2004). In adult fish studied, Cyp19b expression varies seasonally, depending on reproductive cycle. For instance, in goldfish (Gelinas et al., 1998) and channel catfish (Kazeto et al., 2003; Kazeto et al., 2005; Rasheeda et al., 2010), it was reported thatCyp19b transcript level begins to increase during ovarian recrudescence (from preparatory phase to regressed phase), increases further in the pre-spawning phase, and is followed by a steep decline. In accordance with these reports, the low Cyp19b mRNA level which is found in the hypothalamus and ovary of RA A. tarichi were anticipated because the ovaries of these fish include only cortical alveoli oocytes during the vitellogenic stage (Ünal et al., 2007). This low Cyp19b mRNA 
level in the hypothalamus and ovary of RA fish from VER suggest that $A$. tarichi from VER may have been exposed to EDC/s which down-regulates the brain aromatase expression in some fish.

The level of $A$. tarichi Cyp19a mRNA was significantly lower in the ovary of RA fish than in RN fish tissue, while no differences were found in the brain of both RA and RN fish. Ovarian aromatase expression begins after brain aromatase expression during early embryonic development and peaks during gonad development (Chiang et al., 2001; Kishida et al., 2001; Matsuoka et al., 2006). These results suggest that the high expression of Cyp19a may be necessary in trigger gonadal differentiation. Also in adult fish, high expression of Cyp19a is necessary for vitellogenesis. In the adult fathead minnow (Pimephales promelas) ovarian aromatase activity and Cyp19atranscript were higher in reproductively active fish (vitellogenic oocyte) than non-reproductive (maturation stage) and juvenile fish (Villeneuve et al., 2006). Similarly, in the rainbow trout, Oncorhynchus mykiss (Nakamura et al., 2005) and Atlantic croaker, (Micropogonias undulates) (Nunez and Applebaum, 2006), P450aromatase transcript levels were higher in the middle vitellogenic stage than in post vitellogenic and post-ovulated follicles. In situ hybridization studies have shown that Cyp19a mRNA expression was localized in the

\section{REFERENCES}

Barney, M.L., Patil, J. G., Gunasekera, R. M. \& Carter, C. G. (2008). Distinct cytochrome P450 aromatase isoforms in the common carp (Cyprinus carpio): Sexual dimorphism and onset of ontogenic expression. General and Comparative Endocrinology, 156(3), 499-508. DOI:10.1016/j.ygcen.2008.03.013

Callard, G. V., Tchoudakova, A. V., Kishida, M. \& Wood, E. (2001). Differential tissue distribution, developmental programming, estrogen regulation and promoter characteristics of cyp19 genes in teleost fish. The Journal of Steroid Biochemistry and Molecular Biology, 79(1-5), 305-314. DOI:10.1016/S0960-0760(01)00147-9

Chang, X., Kobayashi, T., Senthilkumaran, B., Kobayashi-Kajura, H., Sudhakumari, C. C. \& Nagahama, Y. (2005). Two types of aromatase with different encoding genes, tissue distribution and developmental expression in Nile tilapia (Oreochromis niloticus). General and Comparative Endocrinology, 141(2), 101-115. DOI:10.1016/j.ygcen.2004.11.020

Cheshenko, K., Brion, F., Le Page, Y., Hinfray, N., Pakdel, F., Kah, O., ... Eggen, R. I. (2006). Expression of zebra fish Aromatase cyp19a and cyp19b genes in response to the ligands of estrogen receptor and aryl hydrocarbon receptor. Toxicological Sciences, 96(2), 255-267. DOI:10.1093/toxsci/kfm003

Cheshenko, K., Pakdel, F., Segner, H., Kah, O. \& Eggen, R. I. (2008). Interference of endocrine disrupting chemicals with aromatase CYP19 expression or activity, and consequences for reproduction of teleost fish. General and Comparative Endocrinology, 155(1), 31-62. DOI:10.1016/j.ygcen.2007.03.005

Chiang, E. F., Yan, Y., Guiguen, Y., Postlethwait, J. \& Chung, B. (2001). Two Cyp19 (P450 Aromatase) genes on duplicated Zebrafish chromosomes are expressed in ovary or brain. Molecular Biology and Evolution, 18(4), 542-550. DOI:10.1093/oxfordjournals.molbev.a003833

Dong, W. \& Willett, K. L. (2008). Local expression of CYP19A1 and CYP19A2 in developing and adult killifish (Fundulus heteroclitus). General and Comparative Endocrinology, 155(2), 307-317. DOI:10.1016/j.ygcen.2007.05.018 follicle cell layer in the pre-vitellogenic and vitellogenic stages of growth while no signal was seen in the primary growth and maturation stage (Dong and Willett, 2008; Kazeto et al., 2004). According to our results, the low Cyp19a mRNA expression in the ovary from RA fish which included cortical alveoli but not pre-vitellogenic and vitellogenic oocytes from RA A. tarichi (Ünal et al., 2007) would be expected result. These low Cyp19a mRNA levels in the hypothalamus and ovary of RA fish from VER suggest that $A$. tarichi in VER may have been exposed to EDC which is unknown factor, such as down-regulates the ovarian aromatase expression in a subset fish (RA).

In conclusion, we suggest that the RA fish represent a segment of the population which may be more sensitive to EDC exposure. Further studies are required to determine the primary sites and the causes of these reproductive abnormalities in A. tarichi in VER of Lake Van.

\section{ACKNOWLEDGMENTS}

This work was supported by National Institue of Environmental Health Sciences (NIEHS) 07381 to Dr. lan P. Callard. We want to thank Kellie A. Cotter and Rebecca Meyer for technical advice, and Burak Kaptaner, Ertugrul Kankaya and Ahmet R. Oğuz for fish sampling.
EPA (2001). Sampling procedures for the 2001 National Sewage Sludge Survey. Office of Science and Technology Washington, D.C. www.epa.gov.

Fenske, M. \& Segner, H. (2004). Aromatase modulation alters gonadal differentiation in developing zebrafish (Danio rerio). Aquatic Toxicology, 67(2), 105-126. DOI: 10.1016/j.aquatox.2003.10.008

Forlano, P. M., Deitcher, D. L., Myers, D. A. \& Bass, A. H. (2001). Anatomical distribution and cellular basis for high levels of Aromatase activity in the brain of teleost fish: Aromatase enzyme and mRNA expression identify glia as source. The Journal of Neuroscience, 21(22), 8943-8955. DOI:10.1523/JNEUROSCI.21-22-08943.2001

Gelinas, D., A. Pitoc, G. \& V. Callard, G. (1998). Isolation of a goldfish brain cytochrome P450 aromatase CDNA:. Molecular and Cellular Endocrinology, 138(1-2), 81-93. DOI: 10.1016/S0303-7207(98)00015-X

Greytak, S. R., Champlin, D. \& Callard, G. V. (2005). Isolation and characterization of two cytochrome P450 aromatase forms in killifish (Fundulus heteroclitus): Differential expression in fish from polluted and unpolluted environments. Aquatic Toxicology, 71(4), 371-389. DOI:10.1016/j.aquatox.2004.12.007

Kazeto, Y., Goto-Kazeto, R., Place, A. \& Trant, J. (2003). Aromatase expression in zebrafish and channel catfish brains: Changes in transcript abundance associated with the reproductive cycle and exposure to endocrine disrupting chemicals. Fish Physiology and Biochemistry, 28(14), 29-32. DOI:10.1023/B:FISH.0000030466.23085.94

Kazeto, Y., Place, A. R. \& Trant, J. M. (2004). Effects of endocrine disrupting chemicals on the expression of CYP19 genes in zebrafish (Danio rerio) juveniles. Aquatic Toxicology, 69(1), 25-34. DOI: 10.1016/j.aquatox.2004.04.008

Kazeto, Y. \& Trant, J. M. (2005). Molecular biology of channel catfish brain cytochrome P450 aromatase (CYP19A2): Cloning, preovulatory induction of gene expression, hormonal gene regulation and analysis of promoter region. Journal of Molecular Endocrinology, 35(3), 571-583. DOI:10.1677/jme.1.01805 
Kishida, M. \& Callard, G. V. (2001). Distinct cytochrome p450 Aromatase Isoforms in Zebrafish (Danio rerio) brain and ovary are differentially Programmedand estrogen regulated during early Development. Endocrinology, 142(2), 740-750. doi.org/10.1210/endo.142.2.7928

Kishida, M., McLellan, M., Miranda, J. A. \& Callard, G. V. (2001). Estrogen and xenoestrogens upregulate the brain aromatase isoform (P450aromB) and perturb markers of early development in zebrafish (Danio rerio). Comparative Biochemistry and Physiology Part B: Biochemistry and Molecular Biology, 129(2-3), 261-268. DOI:10.1016/S1096-4959(01)00319-0

Kwon, J. Y., McAndrew, B. J. \& Penman, D. J. (2001). Cloning of brain aromatase gene and expression of brain and ovarian aromatase genes during sexual differentiation in genetic male and female Nile tilapia Oreochromis niloticus. Molecular Reproduction and Development, 59(4) 359-370. DOI:10.1002/mrd.1042

Lange, A., Katsu, Y., Ichikawa, R., Paull, G. C., Chidgey, L. L., Coe, T. S. \& Tyler, C. R. (2008). Altered sexual development in roach (Rutilus rutilus) exposed to environmental concentrations of the pharmaceutical $17 \mathrm{a}$ Ethinylestradiol and associated expression dynamics of Aromatases and estrogen receptors. Toxicological Sciences, 106(1), 113-123. DOI: $10.1093 /$ toxsci/kfn151

Marttinen, S. K., Kettunen, R. H., Sormunen, K. M. \& Rintala, J. A. (2003). Removal of bis(2-ethylhexyl) phthalate at a sewage treatment plant. Water Research, 37(6), 1385-1393. DOI: 10.1016/S0043-1354(02)00486-4

Matsuoka, M. P., Van Nes, S., Andersen, Ø., Benfey, T. J. \& Reith, M. (2006). Real-time PCR analysis of ovary- and brain-type aromatase gene expression during Atlantic halibut (Hippoglossus hippoglossus) development. Comparative Biochemistry and Physiology Part B: Biochemistry and Molecular Biology, 144(1), 128-135. DOI: 10.1016/j.cbpb.2006.02.008

Nakamura, I., Evans, J. C., Kusakabe, M., Nagahama, Y. \& Young, G. (2005). Changes in steroidogenic enzyme and steroidogenic acute regulatory protein Messenger RNAs in ovarian follicles during ovarian development of rainbow trout (Oncorhynchus mykiss). General and Comparative Endocrinology, 144(3), 224-231. DOI:10.1016/j.ygcen.2005.06.004

Nunez, B. S. \& Applebaum, S. L. (2006). Tissue- and sex-specific regulation of CYP19A1 expression in the Atlantic croaker (Micropogonias undulatus). General and Comparative Endocrinology, 149(2), 205-216. DOI:10.1016/j.ygcen.2006.06.005

Pasmanik, M. \& Callard, G. V. (1985). Aromatase and 5a-reductase in the teleost brain, spinal cord, and pituitary gland. General and Comparative Endocrinology, 60(2), 244-251. DOI:10.1016/0016-6480(85)90320-X
Pfaffl, M. W. (2001). A new mathematical model for relative quantification in real-time RT-PCR. Nucleic Acids Research, 29(9), $45 \mathrm{e}-45$. DOI:10.1093/nar/29.9.e45

Rasheeda, M., Sridevi, P. \& Senthilkumaran, B. (2010). Cytochrome P450 aromatases: Impact on gonadal development, recrudescence and effect of hCG in the catfish, Clarias gariepinus. General and Comparative Endocrinology, 167(2), 234-245. DOI:10.1016/j.ygcen.2010.03.009

Sawyer, S. J., Gerstner, K. A. \& Callard, G. V. (2006). Real-time PCR analysis of cytochrome P450 aromatase expression in zebrafish: Gene specific tissue distribution, sex differences, developmental programming, and estrogen regulation. General and Comparative Endocrinology, 147(2), 108-117. DOI:10.1016/j.ygcen.2005.12.010

Simon, P. (2003). Q-gene: Processing quantitative real-time RT-PCR data. Bioinformatics, 19(11), 1439-1440. DOI:10.1093/bioinformatics/btg157

Tchoudakova, A. \& Callard, G. V. (1998). Identification of multiple CYP19 genes encoding different cytochrome P450 Aromatase Isozymes in brain and ovary*. Endocrinology, 139(4), 2179-2189. DOI:10.1210/endo.139.4.5899

Tchoudakova, A., Kishida, M., Wood, E. \& Callard, G. V. (2001). Promoter characteristics of two cyp19 genes differentially expressed in the brain and ovary of teleost fish. The Journal of Steroid Biochemistry and Molecular Biology, 78(5), 427-439. DOI:10.1016/S0960-0760(01)00120-0

Unal, G., Çetinkaya, O. \& Elp, M. (1999). Histological Investigation of Gonad Development of Chalcalburnus tarichi (P. 1811). Turkish Zoology, 23, 329-338. DOI:10.1016/j.ygcen.2006.06.005

Unal, G., Marquez, E. C., Feld, M., Stavropoulos, P. \& Callard, I. P. (2014). Isolation of estrogen receptor subtypes and vitellogenin genes: Expression in female Chalcalburnus tarichi. Comparative Biochemistry and Physiology Part B: Biochemistry and Molecular Biology, 172-173, 6773. DOI:10.1016/j.cbpb.2014.04.002

Ünal, G., Türkoğlu, V., Oğuz, A. R. \& Kaptaner, B. (2007). Gonadal histology and some biochemical characteristics of Chalcalburnus tarichi (Pallas, 1811) having abnormal gonads. Fish Physiology and Biochemistry, 33(2), 153-165. DOI:10.1007/s10695-006-9126-1

Villeneuve, D.L., Knoebl, I., Kahl, M. D., Jensen, K. M., Hammermeister, D. E., Greene, K. J. \& Ankley, G. T. (2006). Relationship between brain and ovary aromatase activity and isoform-specific aromatase mRNA expression in the fathead minnow (Pimephales promelas). Aquatic Toxicology, 76(3-4), 353-368. DOI:10.1016/j.aquatox.2005.10.016 